\title{
Appendiceal Carcinoma pTX TNM Finding v7
}

National Cancer Institute

\section{Source}

National Cancer Institute. Appendiceal Carcinoma pTX TNM Finding v7. NCI Thesaurus. Code C89895.

Appendiceal carcinoma in which the primary tumor cannot be assessed. (from AJCC 7th Ed.) 